\title{
Keanekaragaman dan Kemelimpahan Tumbuhan Paku di Cagar Alam Donoloyo sebagai Bahan Pengembangan Multimedia Interaktif Biologi di SMA
}

\author{
Fitria Nur Hasanah \\ Program Studi Pendidikan Biologi Universitas Veteran Bangun Nusantara Sukoharjo \\ Email : fitria_n100@yahoo.com
}

\begin{abstract}
This study aims 1) to determine the index of species abundance, characteristics, morphology of ferns in the nature reservearea of Donoloyo, Watusomo, slogohimo 2) to obtain an alternative source of learning biology in high school about the abundance of ferns based on interactive multimedia in the form CD 3) to find out the multimedia validation of interactive learning biology of ferns. This research method is descriptive quantitative exploration, the instrument used is a direct observation technique with the quadrat method and validation sheet. The results of the study showed that in the Donoloyo nature reserve, 12 species of ferns were found in 2 classes and 5 families which showed in the medium category. Observations of ferns are used as learning resources in the form of interactive multimedia learning. The quality of interactive media assessed by 3 validators namely material experts, media experts, and biology teacher get a percentage >80\% (very valid) interactive multimedia is ready to be used as a learning media for biology in high school.
\end{abstract}

Keywords: diversityand abundance, multimedia interactive learning, ferns

\section{PENDAHULUAN}

Pendidikan di sekolah pada dasarnya merupakan kegiatan belajar mengajar, yaitu interaksi antara guru dan siswa. Keberhasilan suatu pendidikan itu tergantung pada proses belajar mengajar di sekolah. Seiring dengan Perkembangan ilmu pengetahuan dan teknologi yang semakin pesat, dunia pendidikan juga berkembang dengan pesat pula. Perkembangan itulah yang memberikan peluang pada guru sebagai pengelola proses pembelajaran, untuk memanfaatkan suatu obyek sebagai sumber belajar sesuai dengan kurikulum yang berlaku. Siswa dituntut untuk aktif dan mampu mandiri dalam belajar.

Biologi sebagai ilmu memiliki kekhasan tersendiri dibandingkan dengan ilmu-ilmu yang lain. Biologi merupakan salah satu ilmu pengetahuan yang mempelajari makhluk hidup dan kehidupannya dari berbagai aspek persoalan dan tingkat organisasinya. Produk keilmuan biologi berwujud kumpulan fakta-fakta maupun konsep-konsep sebagai hasil dari proses keilmuan biologi (Sudjoko, 2001:2).

Pada perkembangan saat ini, ilmu pengetahuan dan teknologi (IPTEK) berkembang secara pesat dan tersebar secara meluas sehingga mempengaruhi segenap bidang kehidupan, termasuk dalam bidang pendidikan. Komputer sebagai salah satu perkembangan teknologi telah bergeser penggunaannya sebagai sumber belajar. Dalam kegiatan pembelajaran penggunaan komputer digunakan untuk menerapkan konsep efektivitas, membantu manusia mengerkjakan tugas-tugas tertentu dengan baik, cepat, tepat, dan menyenangkan.

Berdasarkan hasil wawancara dengan guru SMA N 1 Slogohimo, SMA N 1 Jatisrono dan SMAN 1 Girimarto diketahui bahwa kebanyakan nilai mata pelajaran biologi pada bab plantae materi tumbuhan paku masih banyak yang belum tuntas dan masih belum bisa memahami materi tersebut. 
Prosentase nilai yang tuntas di bawah $60 \%$ dari KKM yang telah ditetapkan di SMA. Pembelajaran biologi kelas $\mathrm{X}$ ini banyak dilakukan di kelas dan media yang digunakan hanya terbatas pada buku saja yang akan mengakibatkan siswa bosan yang akan mengakibatkan nilainya di bawah KKM.

Seiring dengan perkembangan zaman, sumber-sumber belajar yang tersedia di lingkungan sekitar masih kurang di manfaatkan sehingga pelaksanaan proses belajar mengajar juga kurang optimal yang mengakibatkan mutu pendidikan belum bisa tercapai. Seperti halnya kita bisa memanfaatkan lingkungan di sekitar kita sebagai sumber belajar dan dapat dikembangkan sebagai media pembelajaran. Kebanyakan kegiatan pembelajaran di sekolahan hanya memanfaatkan konsep yang berasal dari buku, tidak langsung menggunakan objek nyata. Ini yang menyebabkan siswa kurang memahami konsep materi yang disampaikan oleh guru. Padahal siswa mampu mengingat materi jika memanfaatkan objek secara nyata atau secara langsung.

Proses pembelajaran merupakan proses komunikasi dan berlangsung dalam suatu system, maka media pembelajaran menempati posisi yang cukup penting sebagai salah satu komponen system pembelajaran. Tanpa media, komunikasi tidak akan terjadi dan proses pembelajaran sebagai proses komunikasi juga tidak akan berlangsung secara optimal.

Media pembelajaran meliputi alat yang secara fisik digunakan untuk menyampaikan isi materi pengajaran yang terdiri dari antara lain buku, tape recorder, kaset, video kamera, video recorder, film, slide (gambar bingkai) dan computer. Dengan kata lain media adalah komponen sumber belajar atau wahana fisk yang mengandung materi instruksional dilingkungan siswa yang dapat merangsang siswa untuk belajar (Gagna dan Briggs, 1925 dalam Surtikanti dan Sri Hartini, 2009:4).

Hutan merupakan salah satu ekosistem yang didalamnya terdapat berbagai komponen dan memiliki keanekaragaman hayati yang sangat tinggi. Hal ini merupakan suatu kekayaan yang tidak ternilai dan mempunyai potensi genetic yang besar pula. Hutan merupakan gudang plasma nutfah dari berbagai jenis tumbuhan dan hewan. Jika hutan rusak, dapat dipastikan akan terjadi erosi plasma nutfah yang akan berakibat punahnya bernbagai kehidupan yang awalnya berada dihutan serta menurunnya keanekaragaman hayati merupakan sumber daya alam sangat bermanfaat.

Tumbuhan paku merupakan suatu divisi yang warganya telah jelas mempunyai kormus, artinya tubuhnya dengan nyata dapat dibedakan dalam tiga bagian pokoknya, yaitu akar, batang, dan daun. Namun demikian, pada tumbuhan paku belum dihasilkan biji (Gembong Tjitrosoepomo, 2003:219). Berbagai jenis tumbuhan paku dapat dijumpai mulai dari daerah pantai (hutan bakau), dataran rendah, rawa, sawah tegalan, kebun, sampai kawasan pegunungan. Tumbuhan paku dapat hidup di tempat yang lembab, umumnya jumlah jenis tumbuhan paku di daerah pegunungan lebih banyak dari pada di dataran rendah. Hal ini disebabkan oleh kelembaban yang tinggi, banyaknya aliran air dan adanya kabut, banyaknya curah hujan pun mempengaruhi jenisnya (Sastrapradja, 1979:7, dalam Anita C Devi, 2016).

Kawasan Cagar Alam Donoloyo yang terletak di Desa Watusomo menyimpan pesona keanekaragaman hayati yang tinggi, 
tentunya berbagai jenis tumbuhan yang terdapat di Cagar Alam Donoloyo tersebut melimpah dan dapat tumbuh dengan baik. Meskipun tumbuhan paku memiliki keanekaragaman yang tinggi serta mampu hidup dalam kondisi lingkungan yang bervariasi, berbagai jenis tumbuhan tertentu terancam kelestariannya karena rusaknya ekosistem akibat tekanan ekonomi dan teknologi yang ditebangi untuk kepentingan sendiri. Berdasarkan hasil wawancara dengan Bapak Totok selaku Mandor di Kawaan Cagar Alam Donoloyo bahwa belum pernah ada yang melakukan penelitian di tempat tersebut khususnya terhadap tumbuhan paku.

Berdasarkan alasan di atas salah satu tempat yang merupakan vegetasi tumbuhan paku di Indonesia adalah kawasan Cagar Alam Donoloyo kecamatan Slogohimo, kabupaten wonogiri, Jawa Tengah. Tumbuhan paku di daerah ini belum dieksplorasi jenisnya, maka dari itu peneliti tertarik untuk melakukan penelitian dengan judul "Studi Eksistensi Keanekaragaman dan Kemelimpahan Tumbuhan Paku di Kawasan Cagar Alam Donoloyo Desa Watusomo Kecamatan Slogohimo Sebagai Bahan Pembuatan Multimedia Pembelajaran Interaktif Mata Pelajaran Biologi SMA Kelas X Semester Genap".

Tujuan penelitian ini adalah Untuk mengetahui indeks kemelimpahan jenis, ciri, morfologi tumbuhan paku di kawasan Cagar Alam Donoloyo Desa Watusomo Kecamatan Slogohimo, Untuk memperoleh salah satu alternative sumber belajar biologi di SMA tentang kemelimpahan jenis tumbuhan paku yang berbasis Multimedia Interaktif berupa CD pada KD "Menerapkan Prinsip Klasifikasi Untuk Menggolongkan Tumbuhan ke dalam Divisio Berdasarkan Pengamatan dan Metagenesis Tumbuhan
Serta Mengaitkan Peranannya dalam Kelangsungan Kehidupan di Bumi”, Untuk mengetahui validasi multimedia pembelajaran interaktif dalam pembelajaran biologi materi tumbuhan paku.

\section{METODE}

Penelitian dilakukan di Kawasan Cagar Alam Donoloyo Desa Watusomo Kecamatan Slogohimo yang dilakukan pada bulan Mei-Juli 2018.

Penelitian ini merupakan penelitian deskriptif kuantitatif eksplorasi dimana deskriptif kuantitatif ini telah memenuhi kaidah-kaidah ilmiah yaitu konkrit/empiris, obyektif, terukur, rasional, dan sistematis. Metode penelitian kuantitatif karena data penelitian berupa angka-angka dan analisis menggunakan statistik (Sugiyono, 2014). Peneliti menggambarkan keadaan suatu variable secara kuantitatif dan di analisis setelah data terkumpul. Instrument yang digunakan pada penelitian ini berupa teknik pengamatan langsung, dengan metode kuadrat. Populasi yang akan diteliti adalah seluruh tumbuhan paku yang ada di Kawasan Cagar Alam Donoloyo Desa Watusomo Kecamatan Slogohimo Kabupaten Wonogiri.

Teknik pengambilan sampel. Dalam penelitian ini membagi lokasi penelitian menggunakan plot. Plot ditempatkan pada setiap stasiun berdasarkan purposive sampling dengan metode kuadrat. Metode kuadrat adalah persegi dengan berbagai ukuran dari $10 \mathrm{~m}^{2}$ sampai $100 \mathrm{~m}^{2}$ (Fachrul, 2007). Dengan pengamatan dibagi menjadi 3 lokasi dengan tiap lokasi dibagi menjadi 3 stasiun ditentukan berdasarkan metode kuadrat. Teknik analisis data dengan mengidentifikasi tumbuhan paku dan menghitung keanekaragaman dengan menggunakan rumus Shannon dan Wiener 
(1949). Besarnya indeks keanekaragaman jenis menurut Shannon-Wienner di definisikan sebagai berikut.

1) Besaran $H^{\prime}<1.5$ menunjukkan keanekaragaman jenis tergolong rendah

2) Besaran $H^{\prime}=1.5 \quad-3.5$ menunkkan keanekaragaman jenis tergolng sedang

3) Besaran $\mathrm{H}^{\prime}>3.5$ menunjukkan keanekaragaman tergolong tinggi (Rusdianto 2014).

Kemudian menyusun angket yang akan diberikan kepada 3 validator untuk menilai kualitas media. Data yang sudah diperoleh dari 3 validator kemudian dihitung prosentase kelayakan produk dengan rentang nilai kelayakan produk menurut Sudjana (2005) dengan modifikasi.

Pembuatan media dilakukan melalui data hasil identifikasi jenis-jenis tumbuhan paku yang telah didapat di Kawasan Cagar Alam Donoloyo Desa Watusomo Kecamatan Slogohimo, selanjutnya dari hasil penelitian tersebut dibuat media pembelajaran berbentuk multimedia interaktif. Multimedia interaktif yang dimaksud adalah powerpoint dengan indikator pencapaian, tujuan pembelajaran, video, materi, dan evaluasi dalam bentuk soal post tes. Selanjutnya perencanaan kegiatan pembuatan media berbasis multimedia interaktif kemudian dikembangkan berupa powerpoint dan uji kelayakan ahli media dan materi oleh dosen, dan uji kelayakan praktisi oleh guru Biologi SMA.

\section{HASIL DAN PEMBAHASAN}

Dalam penelitian ini di ambil tiga lokasi penelitian meliputi lokasi I bagian timur Cagar Alam Donoloyo yang dekat dengan sungai, lokasi II bagian tengah Cagar Alam, dan lokasi ke III bagian barat Cagar Alam Donoloyo. Tiap lokasi penelitian dibagi menjadi 3 stasiun pembagian stasiun dari tiap lokasi penelitian, tiap lokasi penelitian pada stasiun 1 yaitu bagian utara Cagar Alam Donoloyo, stasiun 2 bagian tengah Cagar Alam Donoloyo, sedangkan stasiun 3 bagian selatan dari kawasan Cagar Alam Donoloyo.

Kegiatan pengamatan tumbuhan paku di kawasan Cagar Alam Donoloyo dilakukan pada pagi hari sekitar pukul 07.00 WIB dan sore hari sekitar pukul 16.00 WIB. Dari ketiga lokasi penelitian tidak hanya dilakukan perhitungan jumlah tumbuhan paku yang di temui tetapi juga dilakukan perhitungan faktor lingkungan yang meliputi suhu, kelembaban, ketinggian tempat, $\mathrm{Ph}$ tanah dan kecepatan angina dengan menggunakan alat yang sudah tersedia dari Laboratorium Biologi Universitas Veteran Bangun Nusantara Sukoharjo.

Hasil yang diperoleh dari penelitian ini berupa indeks keanekaragaman dan kemelimpahan, sumber belajar biologi dan validasi media pembelajaran interaktif

Tabel 1. Tabel yang Tidak Cukup ditulis dalam Setengah Halaman

\begin{tabular}{|c|c|c|c|c|c|}
\hline \multirow{2}{*}{ No } & \multirow{2}{*}{ Spesies } & \multicolumn{4}{|c|}{ Kelas } \\
\hline & & Psilophytinae & Lycopodinae & Equisetinae & Filicinae \\
\hline & odium clavatum & & $\sqrt{ }$ & & \\
\hline & ensiformis & & & & $\sqrt{ }$ \\
\hline & vittata & & & & $\sqrt{ }$ \\
\hline & olepis falcate & & & & $\sqrt{ }$ \\
\hline & um tenerum & & & & $\sqrt{ }$ \\
\hline
\end{tabular}




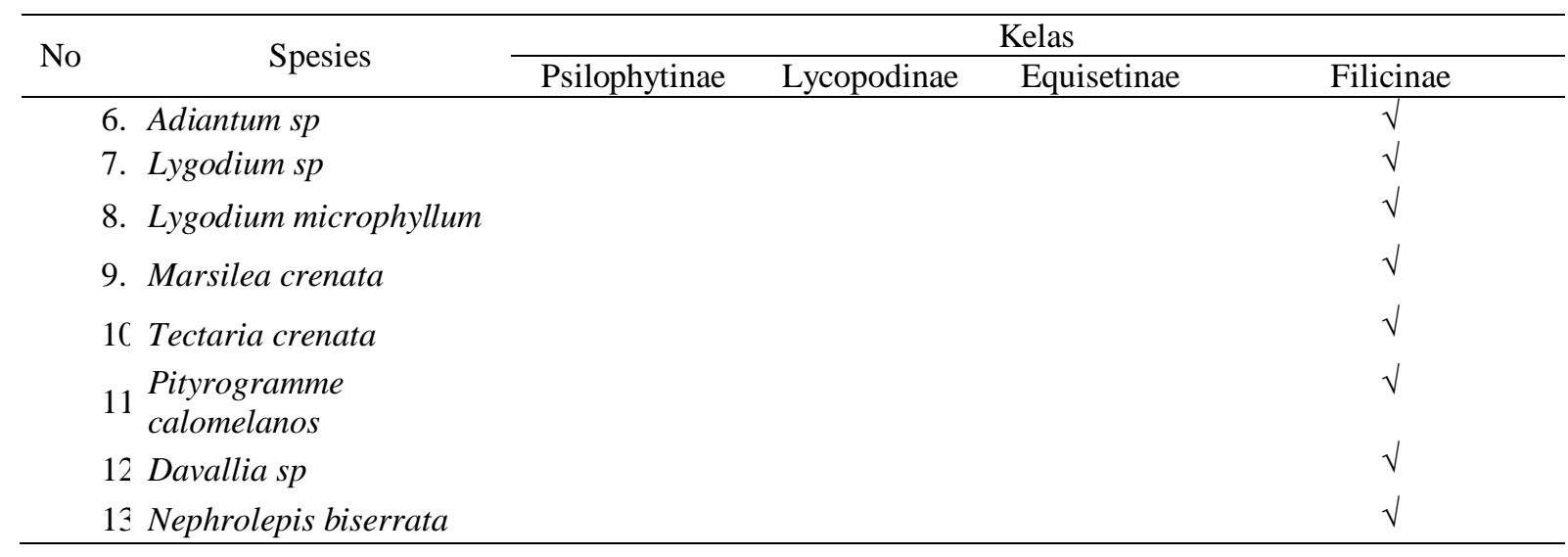

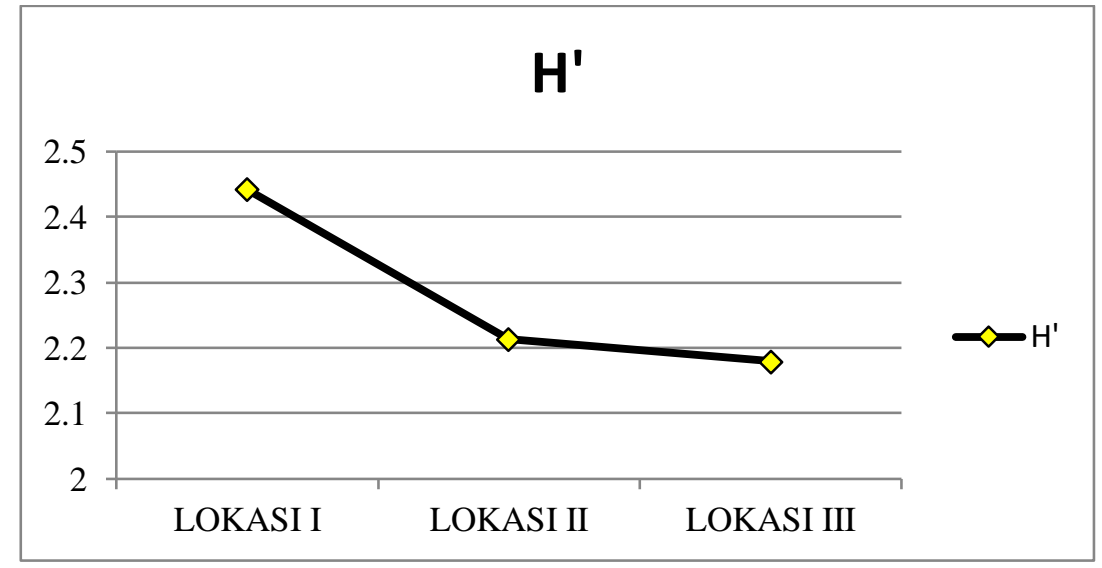

Gambar 1. Grafik indeks keanekaragaman pada lokasi 1, II dan III.

Kemelimpahan tumbuhan paku atau INP di kawasan cagar alam donoloyo pada lokasi I yang paling tinggi adalah pada Famili Polipodiaceae yaitu spesies Lycopodium microphyllum sebesar 21,733 \% dan INP yang terendah pada Famili Marsileaceae pada spesies Marsilea crenata sebesar 6,395\%. Indeks Tingkat keanekaragaman Pteridophyta pada Lokasi I yaitu sebesar $\mathbf{H}^{\prime}=\mathbf{2 . 5 2 5}$ termasuk pada kriteria keanekaragaman sedang.

Berdasarkan hasil pengukuran faktor pengaruh pertumbuhan pada lokasi II suhu udara $25^{\circ} \mathrm{C}$, kelembaban $70 \%$, ketinggian 445 mdpl, dan $\mathrm{pH}$ tanah 6 , dimana tumbuhan tidak terlalu banyak tumbuh karena sinar matahari yang langsung menyinari tanah menyebabkan suhu agak terlalu tinggi sesuai dengan kajian teori yang sudah di bahas pada bab sebelumnya bahwa beberapa tumbuhan paku tidak dapat tumbuh di tempat yang dikenai sinar matahari (Holtum, 1986).

Untuk mengetahui tingkat kemelimpahan tumbuhan paku dapat diketahui dari INP pada masing-masing spesies yang ditemukan. Dari data yang diperoleh dianalisis terlihat bahwa INP tertinggi yaitu Famili Polipodiaceae pada spesies Pteris vittata yaitu sebesar 27,83\%, sedangkan INP terendah yaitu Famili Marsileaceae pada spesies Marsilea crenata $5,28 \%$. Indeks keanekaragaman tumbuhan paku di Kawasan Cagar Alam Donoloyo pada lokasi II dianalisis dengan menggunakan H' Indeks Shannon and Wiener. Dari data yang diperoleh H' sebesar 2,214 . 
Berdasarkan pengukuran faktor lingkungan pada lokasi III dengan suhu $28^{\circ} \mathrm{C}$, kelembaban $62 \%$, ketinggian $445 \mathrm{mdpl}$ dan $\mathrm{pH}$ tanah 6. Pada lokasi penelitian III mengalami perbedaan hasil pengukuran kelembaban udara dikarenakan kelembaban udara berbanding terbalik dengan suhu udara, semakin tinggi kelembaban udara maka suhu udara semakin rendah (Ardhana, 2012).

INP tumbuhan paku pada pengamatan lokasi III yang tertinggi yaitu spesies Pteris ensiformis sebesar 26,66 \% dan yang terendah yaitu spesies Pityrogramme calomelanos sebesar 20,14 \%. Indeks keanekaragaman tumbuhan paku pada lokasi ini yaitu sebesar $\mathrm{H}^{\prime}=2.18$ masih termasuk dalam kategori indeks keanekaragaman sedang.

Dari seluruh lokasi penelitian spesies yang paling banyak adalah spesies dari kelas Filicinae. Menurut Tjitrosoepomo (1989) kelas Filicinae dari segi ekologis tumbuhan ini termasuk higrofit, banyak tumbuh di tempat-tempat yang teduh dan lembab. Menurut Morgan (2001) tumbuhan paku ini tumbuh di daerah tropis pada umumnya menghendaki kisaran suhu $21-27^{\circ} \mathrm{C}$ untuk pertumbuhannya. Dengan keadaan temperature yang sesuai menyebabkan penyebaran jenis tumbuhan paku banyak di hutan tropis. Dari kelas Filicinae spesies yang banyak ditemukan yaitu dari Famili Polipodiceae, yaitu tumbuhan paku yang memiliki jumlah jenis tertinggi. Hal ini sesuai dengan teori Lawrence (1985), famili Polipodiceae merupakan famili dari tumbuhan paku yang paling banyak jumlahnya, yaitu sekitar 170 genus dan 7000 jenis yang tersebar di seluruh dunia. Untuk spesies yang paling sedikit ditemukan yaitu Marsilea crenata dari Famili Marsileaceae yang hanya ditemukan pada Lokasi penelitian I saja. Spesies ini kebanyakan dapat hidup di daerah air dikarenakan pada lokasi 1 berada di tepi sungai berbeda dengan lokasi 2 dan lokasi 3.

Tumbuhan paku yang paling banyak ditemukan adalah dari kelas Flicinae dan paing sedikit yaitu dari kelas Lycopodinae sesuai dengan teori yang menyatakan di kawasan kepulauan Indonesia diperkirakan terdapat 4000 jenis tumbuhan paku yang mayoritasnya dari kelas Filicinae (1995). Kebanyakan jenis tumbuhan paku yang ditemukan hidupnya secara terestrial.

Keanekaragaman di Kawasan Cagar Alam Donoloyo menunjukkan bahwa indeks keanekaragaman tumbuhan paku tergolong kategori sedang karena berada pada kisaran angka diatas $1,5-2,5=$ indeks keanekaragaman sedang (Rusdianto, 2014).

\begin{tabular}{ccc}
\hline Validator & Penguji Media & Skor \\
\hline Validator 1 & Ahli Materi & $83,33 \%$ \\
Validator 2 & Ahli Media & $95,83 \%$ \\
Validator 3 & Guru Biologi & $78,75 \%$ \\
\hline
\end{tabular}

Berdasarkan hasil penilaian yang dilakukan oleh ahli materi diperoleh skor 110. Skor tersebut kemudian dianalisis dengan menggunakan teknis analisis data presentase yaitu skoryang yang diperolehdibagi dengan skor maksimal kemudian dikonversi dalam presentase. Skor maksimal dalam penilaian materi ini adalah 132. Setelah dikonversi dalam bentuk presentase skor menjadi $83.33 \%$. presentase tersebut menunjukkan bahwa materi masuk dalam kategori sangat layak berdasarkan rentan ppresentase $82 \%$ - $100 \%$ termasuk dalam kriteria sangat layak, sehingga secara keseluruhan berdasarkan validasi ahli materi pada materi Pteridophyta (Tumbuhan paku) yang dijadikan sebagai bahan pembuatan 
multimedia interaktif termasuk dalam kategori sangat layak.

Berdasarkan hasil penilaian yang dilakukan oleh ahli media, diketahui skor yang diperoleh sebanyak 92 dengan skor maksimal 96. Skortersebut kemudian dianalisis dengan menggunakan teknis analisis data presentase yaitu skor yang diperoleh dibagi dengan skor maksimal kemudian dikonversi dalam bentuk presentase. Setelah dikonversi dalam bentuk presentase skor menjadi $95.83 \%$. Presentase tersebut menunjukkan bahwa media masuk kategori sangat layak yaitu antara 82\%-100. Sehingga secara keseluruhan berdasarkan validasi ahli media multimedia pembelajaran interaktif masuk pada kategori sangat layak untuk dimanfaatkan sebagai bahan pembelajaran.

Sedangkan untuk penilaian validasi pengguna/praktisi diperoleh skor sebanyak 63 dan skor maksimal 80. Skor tersebut kemudian dianalisis dengan menggunakan teknis analisis data presentase yaitu skor yang diperoleh dibagi dengan skor maksimal kemudian dikonversi dalam bentuk presentase. Setelah dikonversi dalam bnetuk presentase, skor menjadi $78.75 \%$. presentase tersebut menunjukkan bahwa media tersebut masuk dalam kategori layak dengan berdasarkan rentan presentase yaitu 63\%$81 \%$ termasukdalam kategori layak. Sehingga secara keseluruhan berdasarkan validasi pengguna/ahli guru Biologi terhadap multimedia pembelajaran interaktif masuk pada kategori layak.

Hasil penilaian ahli materi, ahli media dan ahli pengguna bahwa multimedia pembelajaran interaktif yang dibuat menunjukkan kategori sangat layak dalam mendukung aktivitas pembelajaran peserta didik dengan materi tumbuhan paku
(Pteridophyta) untuk Sekolah Menengah Atas kelas X Semester Genap. Kegiatankegiatan belajar dan hasil penelitian padamodul ini diharapkan dapat menarik motivasi dan meningkatkan hasil belajar siswa. Hasil penelitian Sulastri, Wiharti, Nugroho (2019) dalam penelitiannya juga mengembangkan modul biologi berbasis penelitian. Modul biologi yang berbasis penelitian dapat meningkatkan aktivitas dan hasil belajar siswa.

\section{KESIMPULAN DAN SARAN}

Berdasarkan data pengamatan dan hasil pembahasan maka dapat disimpulkan bahwa Indeks keanekaragaman tumbuhan paku di Kawasan Cagar Alam Donoloyo dari ketiga lokasi termasuk dalam kategori sedang yaitu berada pada angka $1,5 \geq \mathrm{H}^{\prime} \geq 3,5$. Keanekaragaman tumbuhan paku yang termasuk tinggi yaitu pada lokasi I dengan nilai $H^{\prime}=2.442$ dan terendah pada lokasi II dengan nilai H' sebesar 2,214 dan lokasi III dengan nilai $\mathrm{H}^{\prime}=2.18$, tumbuhan paku yang diperoleh sebanyak 12 spesies dengan ciri dan morfologi tumbuhan paku yang berbeda. Produk penelitian ini dapat digunakan sebagai bahan pembuatan multimedia pembelajaran interaktif tentang dunia tumbuhan (plantae) pteridophyta dengan memanfaatkan lingkungan sekitar untuk pengamatan dan untuk pendamping pada saat pembelajaran berlangsung dengan bentuk CD. Kualitas media interaktif yang dinilai oleh 3 validator yaitu ahli media, ahli materi, dan guru biologi/pengguna memperoleh prosentase $>80 \%$ (sangat valid) multimedia interaktif siap digunakan sebagai media pembelajaran biologi di SMA. 


\section{DAFTAR PUSTAKA}

Devy, A Candra. (2016). Keanekaragaman dan Kelimpahan Tumbuhan Paku di Kawasan Taman Hutan Raya Ir. H. Djuanda Dago Pakar Bandung. Diakses dari: http//repository.unpas.ac.i/13882/ (Diakses 12 Desember 2017 pukul 11:31 WIB).

Fachrul, M.F. (2007). Metode Sampling Bioekologi. Jakarta : Bumi Aksara.

Sugiyono. (2014). Metode Penelitian Kuantitatif Kualitatif dan $R \& G$. Bandung: Alfabeta

Sulastri, S., Wiharti, T., \& Nugroho, A. A. (2019). Keanekaragaman Tumbuhan Paku di Kawasan Wisata Alam Candi Muncar Wonogiri Sebagai Bahan Penyusunan Modul Pembelajaran. Journal of Biology Learning, 1(1).

Tjitrosoepomo, Gembong. (1989). Taksonomi Tumbuhan. Yogyakarta: Gajah Mada Press. 